\title{
Classification of soils in Slovenia
}

\author{
Blaž Repe ${ }^{1 *}$ \\ ${ }^{1}$ Geography Department, Faculty of Arts, University of Ljubljana, Aškerčeva 2, 1000 Ljubljana, Slovenia \\ * PhD Blaž Repe, blaz.repe@ff.uni-lj.si, ORCID iD: https://orcid.org/0000-0002-5530-4840
}

Received: August 25, 2019

Accepted: April 29, 2020

Associated editor: C. Kabała

\section{Keywords}

Slovenia

Yugoslavia

Soil classification

Soil type

WRB

\begin{abstract}
The roots of the modern classification of soils in Slovenia can be traced to the 19th century when Croatian Kišpatić produced the first soil classification, which included soils for the part of Slovenian territory. Since the beginning of the 20th century until Slovenia's independence in 1991 soil classification was heavily interlinked to the territory of former Yugoslavia. Slovenia had been its integral part and the Yugoslavian Soil Classification developed together with Serbians, Croatians, Macedonians, Slovenians etc. The foundations have been set in the 50' and 60' when genetic approach was accepted and first concepts and papers have been published. In 70,' a project of intensive soil mapping and field surveying began and therefore grew the needs for the development of Yugoslavian Soil Classification. It was constantly developing, updating and being presented during numerous congresses of Yugoslav Soil Science Society until mid-80'. The highest level of soil classification was (is) the soil order, defined by the presence and action of water (automorphic, hydromorphic, saline and subaqueous). The orders were (are) divided to classes mainly on the bases of soil development (presence and sequence of genetic horizons, i.e. soil profile). The unit on the third and most important level was and still is a soil type (Soil division-Soil class-Soil type-Subtype-Variety-Form). They are distinguished by the presence of certain parent material or the occurrence of specific soil forming processes. After the breakup of Yugoslavia, Slovenia adopted and retained the Yugoslavian concept and the activities related to the Slovenian Soil Classification simply continued. Today Slovenian soil classification has 27 major soil types and was adapted from Yugoslavian to the national needs and specifics. In a number of aspects it is similar to the German Soil Classification. In the past decade there is growing need for the improvement of the Sloveniansoil classification that would apart from productivity, water holding capacity, organic matter content reflect also soil functions, sensitivity or resilience to environmental threats, ecosystem services etc. In spite of many efforts, no official document has been published yet. As a Lingua Franca Slovenian soil scientists use WRB. Slovenia got its official translation of the latest version of the WRB in 2018.
\end{abstract}

\section{Introduction}

Classification is an act or process of classifying. The latter being a systematic arrangement in groups or categories according to established criteria as stated in the Merriam-Webster Dictionary (website 1). Classifications are also an orderly ways to present information and, depending upon their objectives, can be artificial or natural. While classifying flora, classifications that use single or at most only a few characteristics to group plants can usually be referred as artificial classifications. Natural classifications group together plants with many of the same characteristics and are highly predictive. That is, by enumerating the characteristics of a plant, one can predict the natural group to which it belongs (website 3). But the difference in classifying natural objects (fauna, flora) to the soils is that soils are a continuum of properties and characterises that change in a time and are especially variable in space (Abdulazeez, 2014). We investigate soils at the defined point of the landscape and assume that the investigated soil extents with the same or similar properties in the near surroundings. Investigating soil means recognising soil properties, observing and measuring physical, chemical and biological characteristics. In order to classify soil we have to investigate and establish certain or selected soil properties, because soil classification means a grouping of soils with a similar range of properties (website 2). Soil classification is also s system, how to group together soils with similar properties or attributes (Carter and Bentley, 2016) and which properties are relevant. There were and are many systems, how to classify soils.

People were managing soils since the very beginning of the agrarian civilization and soon they noted that the soils are different (Krasilnikov et al., 2010). Early agrarian civilizations must have had some way to communicate differences and similarities among soils. The earliest documented attempt at 
a formal classification of soils seems to have occurred in China about 40 centuries ago (Ahrens et al., 2002). Theophrastus, an ancient Greek botanist, described clay, sand, stony, salty, swamp, soft, and hard soils and their relation to plant cover. In Rome, Cato (234-149 years B.C.) in his fundamental book "De agricultura" described a number of soil types: white clay, red clay, mottled earth, and friable dark earth. Mid-American civilizations were also known to develop soil classifications: at least 50 terms for various soils were documented for preHispanic Aztec culture (Krasilnikov and Tabor, 2010). In the 19th century, the interest in studying of soils was renewed, especially related to assess soil productivity and therefore easily set the level of taxes. That initiated the establishment of the new science, pedology. In 1882, the Russian Government hired Dokuchaev to guide a program to map and classify soils as a basis for tax assessment (Simonson, 1962). Dokuchaev and his followers started a new pedology (genetic pedology) that promoted the description and characterization of soils as natural bodies with a degree of natural organization rather than as simply mantles of weathered rock (Mermut and Eswaran, 2001; Ahrens, et al. 2002). With Dokuchaev genetic approach had been introduced.

There are two main opposite approaches to soil classification: morphological, that is, focused on the diagnostic properties of soils and, above all, diagnostic horizons, and genetic, of which the former became dominant (Hartemink, 2016). Genetic approach, compared to morphological one provide a deeper understanding of the genesis of the classification objects and a forecast of possible changes in them (Nikiforova, 2019). This approach was widely accepted in many parts of Europe, Germany included (Behrens and Scholten, 2006) which is evident in the works of Kubiëna (Kubiëna, 1948, 1953, 1958): "the knowledge of the genesis of a property is very important in systematics since only by this can a property or a unit of properties be fully known and understood. [...] describing things in nature without any efforts to understand those means only a beginning of science, not science itself (Kubiëna, 1958; as cited in Nikiforova, 2019). Kubiëna's classification prepared ground for many following and present European classifications, also in Yugoslavia (Kralj, 2008).

This short history is important, since the present state of Slovenian Soil Classification is directly connected to the former Yugoslavian classification with its concept and approach. The aim of this paper is to present the evolution of the soil classification that is currently in use in Slovenia.

\section{History of soil classification in Slovenia / Yugoslavia}

The roots of the modern classification of soils in Slovenia can be traced to the 19th century when Croatian Kišpatić (Kišpatić, 1877; as cited in Čirić, 1984) produced the first soil classification which included also soils for the part of Slovenian territory. The classification was adapted from geological, chemical and physical classifications from that period (from the agrogeology school), but it also reflected land quality evaluation used in those times in Germany. Before First World War (1911-1914)
Šandor and Mosković accept Russian genetic approach and used the concept of Sibirtsev and Glinka. The concept was well received and for example persisted in Gračanin's Croatian classification until 1942 (Skorić, 1977). In 1972 Stebut provided first, simple genetic Yugoslavian classification in Serbian and later in 1930 in German language. The classification had three classes: undeveloped, zeolitic (from secondary materials) and destructive stadia with seven recognised processes of soil formation. After Second World War Gračanin (1951) contributed his own, new, genetic classification with soil type as a fundamental unit. Types are then further grouped in orders and three classes (eluviated, equilibriated and accumulated). The lower units were subtypes, varieties, subvarieties, series, subseries and facieses. Kovačevič (1956) and Filipovski (1959) also provided later classifications. In 1963, Neugebauer, Ćirič, Filipovski, Škorić and Živković promoted new "Soil classification of Yugoslavia". It was approved on the $2^{\text {nd }}$ Congress of Yugoslavian pedologists. The classification was genetic; it was based on soil properties, with an aim to serve productive and ecological purposes of soil evaluation. With very little changes it remained in use for nearly a decade (Škorić, 1986). In 1972, on the $4^{\text {th }}$ Congress of Yugoslavian pedologists Škorić, Filipovski and Ćirič proposed new and in fact the last, "new" version of soil classification of Yugoslavia, published in 1973 (Skorić et al., 1973; Skorić, 1977). It was used in the intensive soil survey and production of the general soil maps of Yugoslavia (Slovenia included) (Antić et al., 1980; Čirić, 1984). It was constantly developing, updating and being presented during numerous congresses of Yugoslav Soil Science Society until the last and final version was published in 1985 (Škorić et al., 1985).

Since the beginning of the $20^{\text {th }}$ century till Slovenia's independence in 1991 soil classification was heavily interlinked to the territory of former Yugoslavia. Slovenia had been its integral part and the Yugoslavian Soil Classification developed together with Serbians, Croatians, Macedonians, Slovenians etc. There was no need or reason for separate development. But even before independence modifications and adaptations were proposed by some authors (Stritar, 1973, 1990; Stepančič, 1977). After the breakup of Yugoslavia, Slovenia adopted and retained the Yugoslavian concept and the activities related to the Slovenian Soil Classification simply continued in the same manner. The adaptations differed from author to author, but the common denominator was mainly the exclusion of Yugoslavia soil types that do not exist on the territory of Slovenia (Chernozems, Vertisols etc.). Different purposes (classification itself, soil survey and mapping, forest soils, education in primary and secondary schools, lecturing, field and laboratory work at the university, land evaluation etc.) and practical usage induced more adaptations end even more versions of basically the same classification (Lovrenčak, 1994; Vrščaj and Prus, 1998; Prus, 2000; Lobnik et al., 2003; Urbančič et al., 2005; Lobnik et al., 2006; Repe, 2006a, 2006b, 2010; Kralj, 2008; Kralj and Grčman, 2009). In very recent years, three additional publications were available, where soil classification was also presented: Soils of Slovenia with soil map 1 :25,000 (Vidic et al.,2015), Slovenian soil classification (Prus et al., 2015) and Soils of Slovenia (Vrščaj et al., 2017). 


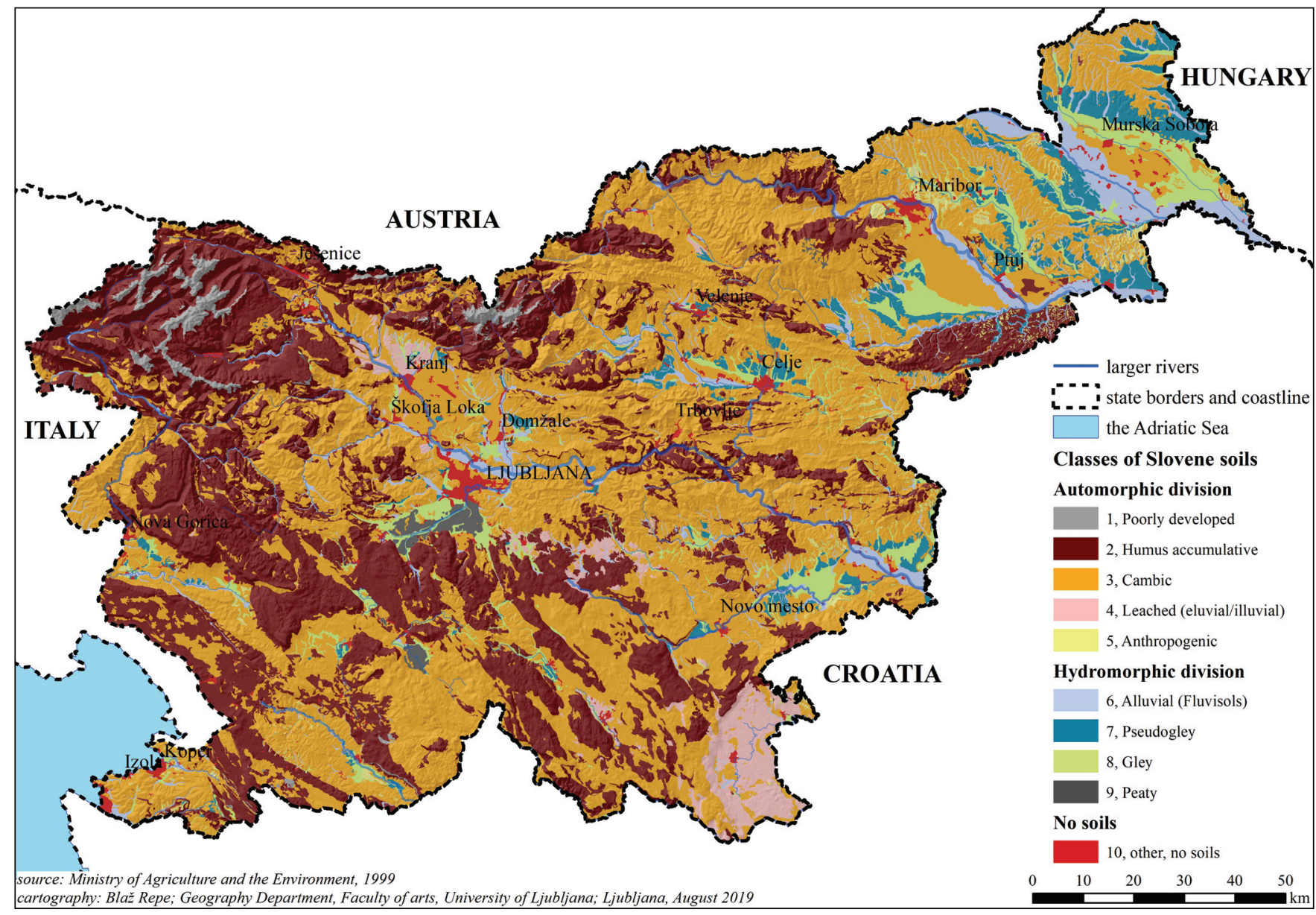

Fig. 1. Soil map of Slovenia

\section{Slovenian soil classification}

The classification of soils on the territory of Slovenia that was used in the past or is currently in use is generally called Slovenian, but it was and in fact still is an adapted variation of the Yugoslavian classification. In his thesis, Kralj (2008) uses the name Modified Yugoslavian Soil Classification (Modifcirana jugoslovanska klasifikacija tal, MJKT. As sad before, there were many adaptations, made by many authors but to this day, never completely commonly agreed or harmonised and to further extent never officially published. In a number of aspects it is similar to the German soil classification.

The main principles of the classification still in use are as follows (Skorić et al., 1973; Skorić, 1977; Antić et al., 1980; Čirić, 1984; Škorić, 1986; Kralj, 2008):

1. Classification is based upon soil properties and not on the factors of soil formation outside pedosphere (for example climate).

2. Soil properties used for classification have to be morphologically visible and easily recognizable or measurable. If possible, quantitative properties are used. Through properties, horizons are precisely defined.

3. Classification is morphologically-genetic with very strong emphasis on soil evolution. While classifying soils into units the sequence and characteristics of horizons is taken into account. Combining units on higher levels is on genetic-evolution principles.

4. Basic soil unit is SOIL TYPE. Combining soil types into units on higher level is based on general and typical criteria. Division of soil types into lower units (subtypes, varieties, forms) is specific for each type. Dividing is done according to soil type characteristic properties and properties that define type variability. Soils on higher level of classification differ more than those on the lower level.

5. Classification serves as a foundation for production-ecological evaluation of soils/land and other derived and specific classifications. Division on lower units uses criteria that have also production significance, not only genetic: soil depth, depth of upper horizons, texture, parent material type, skeletal parts, pH, base saturation (eutric and dystric properties), content of carbonates etc.

6. Human influences are included in the classification. All four basic divisions recognise anthropogenic soils.

7. Architecture of classification enables incorporating new knowledge and adding new units without changing the principle and system of classification.

The present classification has six levels:

Soil division-Soil class-SOIL TYPE-Soil subtype-Soil varietySoil form 
Table 1

Slovenian soil classification, naming and cover according to digital soil map of Slovenia, scale $1: 25,000$ (Website 4)

\begin{tabular}{|c|c|c|c|c|c|}
\hline division & class & type & area $\left[\mathrm{km}^{2}\right]$ & $\%$ & general WRB reference soil group \\
\hline \multirow{13}{*}{ Automorphic } & \multirow{3}{*}{ Poorly developed } & Lithosol & 262.14 & 1.29 & Leptosol (Nudilithic, Hyperskeletic) \\
\hline & & Regosol & 0.67 & 0.00 & Regosol \\
\hline & & Colluvial/deluvial & 1.54 & 0.01 & Regosol \\
\hline & \multirow{2}{*}{$\begin{array}{l}\text { Humus } \\
\text { accumulative }\end{array}$} & Rendzina & 5838.21 & 28.80 & Leptosol (Eutric, Mollic, Rendzic), Phaeozem \\
\hline & & Ranker & 428.62 & 2.11 & Leptosol (Dystric, Umbric), Umbrisol \\
\hline & \multirow{4}{*}{ Cambic } & Eutric brown & 3215.56 & 15.86 & Cambisol (Eutric) \\
\hline & & Brown on limestone and dolomite & 2553.29 & 12.59 & Cambisol (Eutric, Chromic, Rhodic), Luvisol \\
\hline & & Jerovica (Terra Rossa) & 41.61 & 0.21 & Cambisol (Eutric, Rhodic, Chromic), Luvisol \\
\hline & & Dystric brown & 4191.87 & 20.68 & Cambisol (Dystric) \\
\hline & \multirow{2}{*}{$\begin{array}{l}\text { Leached } \\
\text { (eluvial/illuvial) }\end{array}$} & Leached & 482.93 & 2.38 & Luvisol (Acric), Alisol \\
\hline & & Podzol & 1.45 & 0.01 & Podzol \\
\hline & \multirow{2}{*}{ Anthropogenic } & Deeply cultivated and Garden & 192.83 & 0.95 & Regosol, Anthrosol (Hortic) \\
\hline & & Deposol & 2.84 & 0.01 & Technosol \\
\hline \multirow{6}{*}{ Hydromorphic } & \multirow{2}{*}{ Alluvial (Fluvisols) } & Underdeveloped alluvial & 44.88 & 0.22 & Fluvisol (Skeletic) \\
\hline & & Developed alluvial & 970.24 & 4.79 & Cambisol (Fluvic), Fluvisol (Eutric/Dystric) \\
\hline & Pseudogley & Pseudogley & 759.84 & 3.75 & Planosol, Stagnosol \\
\hline & Gley & Gley & 850.93 & 4.20 & Gleysol (Fluvic, Eutric, Dystric, Clayic) \\
\hline & \multirow{2}{*}{ Peaty } & Topogenic peat & 45.00 & 0.22 & Histosol (Eutric, Dystric) \\
\hline & & Ombrogenic peat & 50.06 & 0.25 & Histosol (Fibric) \\
\hline \multirow[t]{2}{*}{ other } & other, no soils & other, no soils & 338.70 & 1.67 & other, no soils \\
\hline & & $\Sigma$ & 20273.19 & 100.00 & \\
\hline
\end{tabular}

The first and broadest level of the classification is the Soil order. The orders are defined and based on the absence/presence of hydromorphic processes and their influences on soil formation. According to soil map Slovenia in a scale $1: 25,000$ (website 4) $84.9 \%$ of soils belong to the automorphic division, the rest are hydromorphic. Divisions 3 (Saline soils) and 4 (Subaqueous soils) are poorly investigated. Saline soils appear only in narrow strip along the coast and are directly influenced by tidal or saline underground water. Subaqueous soils appear on the bottom of the lakes, ponds, slowly flowing rivers and of course on the sea bottom (Repe and Pristovšek, 2011; Povše and Repe, 2013; Repe et al., 2019). On the second level, the Soil orders are divided into Soil classes and are based on the soil profile morphology, mainly the presence and sequence of genetic horizons and soil profile development. The most common is Cambic Soil class with $49.3 \%$ and second are Hummus accumulative soils with $30.9 \%$. The third level accommodates the central and most important unit that is the Soil type. They are distinguished mainly by soil genesis, the presence of certain parent material or the occurrence of specific soil forming processes. Further division to Subtypes, Varieties and Forms is specific for each type. The criteria is unique for each type and they are a selection of morphogenetic and other properties of soil or selected horizon. That makes classification sometimes difficult to work with. On the other hand dividing is specifically tailored for each type and is probably describing soil in the optimum way. There are two examples of further division of types to the lower units (Tables 2 and 3).

Slovenian soil classification recognizes the following main and subhorizons: organic (by stages of decomposition $\boldsymbol{O l}, \boldsymbol{O} \boldsymbol{f}$ and $\boldsymbol{O} \boldsymbol{h}$ ), humus-accumulative (initial $(\boldsymbol{A})$ and general $\boldsymbol{A}$ ), cambic (in situ accumulation of clay by weathering $\boldsymbol{B} \boldsymbol{v}$ or residue from corrosion of limestone and dolomite $\mathbf{B r z}$ ), eluvial and illuvial (general eluvial $\boldsymbol{E}$ and illuvial clayey $\boldsymbol{B t}$, humus enriched $\boldsymbol{B} \boldsymbol{h}$, sesquioxides enriched $\boldsymbol{B} \boldsymbol{f e}$ ), hydromorphic (oxymorphic $\mathbf{G o}$, reductimorphic $\mathbf{G r}$, anaerobic accumulation of organic matter, usually as peat $\boldsymbol{T}$ or $\boldsymbol{H}$ ), parent material (unconsolidated $\boldsymbol{C}$ and hard, solid $\boldsymbol{R}$ ). Other frequently used letters added to explain the properties of the main horizons are the following: $\boldsymbol{b}$ for a buriedhorizon; $\boldsymbol{p}$ for a ploughed or tilled horizon; $\boldsymbol{c}$ for the accumulation of concretions; $\boldsymbol{h}$ for the accumulation of organic matter in the mineral horizons; $g$ for gleyic processes in horizons other than $G$ (commonly for impermeable horizons in Pseudogleys); $\boldsymbol{k}$ for the accumulation of calcium carbonate; $\boldsymbol{q}$ for the accumulation of siliceous materials.

Today Slovenian soil classification has 4 soil divisions, 16 classes, 27 major soil types, and possible 115 subtypes, 74 varieties and 46 forms (Kralj, 2008) and was adapted from Yugoslavian to the national needs and specifics. 
Fig. 2. The architecture of Slovenian soil classification

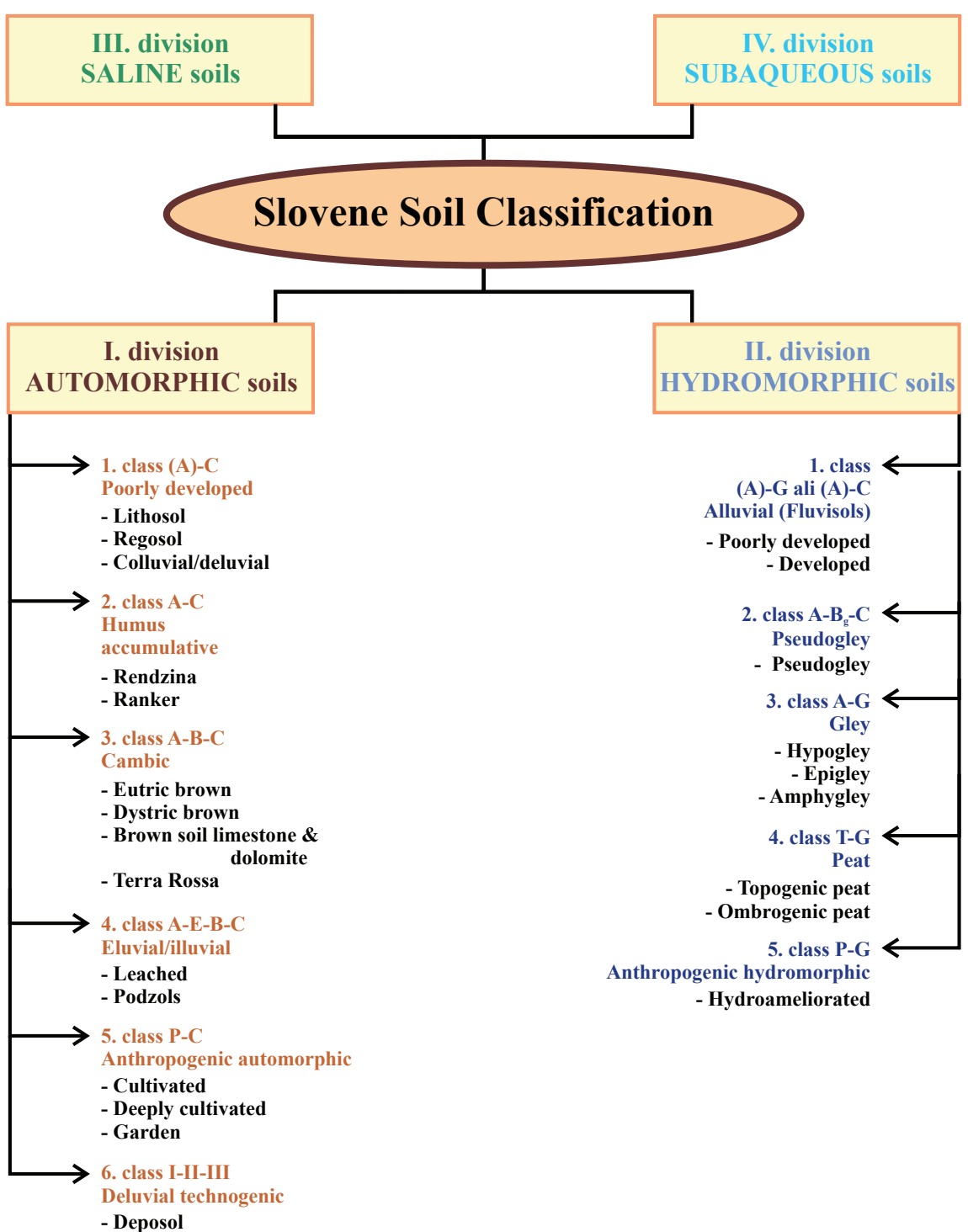

Table 2

Division of Soil type Rendzina to lower units

\begin{tabular}{ll}
\hline Soil order & Automorphic soils \\
\hline Soil class & Humus accumulative \\
\hline Soil type & 4. Rendzina \\
& 4.1 On limestone and dolomite \\
& 4.2 On limestone \\
& 4.3 On dolomite \\
Subtype & 4.4 On soft carbonate rocks (flysch, marl) \\
& 4.5 On unconsolidated carbonate fluvial sand and gravel \\
& 4.6 On moraine \\
& 4.7 On slope gravel \\
& 4.(1-3).1 With raw humus - tangel \\
Variety & 4.(1-7).2. With moder humus \\
& 4.(1-7).3. With mul humus \\
& 4.(1-7).4. Brown (B exists, but is less thick than A) \\
\hline \multirow{2}{*}{ Form } & 4.(1-7).(1-4).1. Shallow (10-20 cm) \\
& 4.(1-7).(1-4).2. Medium (20-30 cm) \\
& 4.(1-7).(1-4).3. Deep (30-45 cm)
\end{tabular}

Table 3

Division of Soil type Gley to lower units

\begin{tabular}{ll}
\hline Soil order & Hydromorphic soils \\
\hline Soil class & Gley \\
\hline Soil type & 19.Hypogley \\
\hline \multirow{2}{*}{ Subtype } & $\begin{array}{l}\text { 19.1 Mineral }(>10 \% \text { humus) } \\
\text { 19.2 Humic (10-30\%) }\end{array}$ \\
\hline \multirow{2}{*}{ Variety } & $\begin{array}{l}\text { 19.(1-2).1Eutric }(\mathrm{V}>50 \%) \\
\text { 19.(1-2).2. Dystric }(\mathrm{V}<50 \%)\end{array}$ \\
& $\begin{array}{l}\text { 19.(1-2).(1-2).1. Weak (Go is between } 50 \text { and } 70 \mathrm{~cm}) \\
\text { 19.(1-2).(1-2).2. Moderately strong } \\
\text { (Go is between } 35 \text { and } 50 \mathrm{~cm})\end{array}$ \\
& $\begin{array}{l}\text { 19.(1-2).(1-2).3. Medium strong } \\
\text { (Go is between } 25 \text { and } 35 \mathrm{~cm})\end{array}$ \\
& $\begin{array}{l}\text { 19.(1-2).(1-2).4. Strong (Go is between } 25 \text { and } 50 \mathrm{~cm}) \\
\text { 19.(1-2).(1-2).5. Very Strong (Go is in the upper } 25 \mathrm{~cm})\end{array}$ \\
\end{tabular}




\section{Conclusions}

The main problem with Slovenian soil classification is, that there is still no official, authority approved and generally accepted document of the classification (only working versions from many authors). However, one of the more practical problems with either existing version of the Slovenian classification is that neither includes soil types or groups outside the state borders, therefore also harmonized terminology does not exist. That makes difficult to name soils around the world while teaching regional soil geography in primary and secondary schools. The curricula, despite appearance of the term WRB, still uses colours as the most important distinguishing and naming parameter for the soils of the world (red, yellow, grey, brown and black soils) (Repe, 2018b). Nevertheless, as a Lingua Franca Slovenian soil scientists use WRB. Slovenia got its official translation of the latest version of the WRB (IUSS Working Group WRB, 2015) in 2018 (Repe, 2018a). It was a common effort of soil geographers and soil scientists, because a new set of soil related terms had to be accepted and harmonized. It is now possible to use internationally accepted and officially translated terms and names also at schools.

Kralj (2008) made a comparison between Slovenian soil classification and WRB (version 2006). He established that WRB is more exact and carries more information, but is perhaps not the most suitable for Slovenian soils, since it does not distinguish between some traditional soil types. Therefore, he proposed a new Slovenian soil classification to be established which would retain some of Slovenian soil classification soil types, but would also use the structure of WRB (2 levels with well-defined qualifiers). In year 2015 (The International Year of Soils) an honest attempt was made to come up with acceptable classification, but it has not been agreed nor officially published. The existing document Slovenian soil classification (Prus et al., 2015) was made publically available on the internet, but to this day remains in a draft version, bearing the mark "work under progress". This version is improved, but not significantly different from the existing version of classification (personal opinion of the author of the paper). In May 2019, a new version started circulating among Slovenian soil scientists and geographers (Vrščaj et al., 2019). The main purpose is to create a modern classification, with accepted terminology and agreed by all sciences that deal with soils (soil science, agronomy, forestry, geography, geology, landscape ecology etc.). The main goals (among others) of the "new" classification intents will be:

- To clearly set the morpho-genetic approach with well-defined field measurements and laboratory analysis of morphological, chemical, physical, biological and anthropogenic properties.

- Define properties, which are important not only from the production aspect, but also for all soil functions and ecological services.

- $\quad$ Set the pedon as a main classification unit.

- Add some new soil types (technogenic, urban) that became important in recent years and are missing from the existing versions.

- Better define some old groups (saline, subaqueous).
- $\quad$ Reduce the number of types, and merge some very similar types (proposed a single type gley, while former three types, epi-, hypo-, amphigley would shift to varieties).

- $\quad$ Retain most of the naming from existing classifications.

- Adaptability of classification to new knowledge and possible newly discovered soil types (soils with vertic properties).

The meetings for possible publications were scheduled for autumn 2019.

In the past decade there was a growing need for the improvement of the Slovenian soil classification that would apart from productivity, water holding capacity, organic matter content reflect also soil functions, sensitivity or resilience to environmental threats, ecosystem services etc. In spite of many efforts and unfortunately there is still no officially accepted, recognized, officially published or generally acknowledged classification document that could carry the name Slovenian soil classification. Fortunately, the near future seems to be bright for Slovenian soil classification.

\section{References}

Abdulazeez, A., 2014. An Account of the Evolution of Soil Classification. Geography of Soils. Bayero University, Kano, Department of Geography.

Ahrens, R.J., Rice, T.J., Eswaran, H., 2002. Soil Classification: Past and Present. National Cooperative Soil Survey Newsletter 2002 (19), 1-5.

Antić, M., Jović, N., Avdalović, V., 1980. Pedologija. Beograd, Naučnaknjiga.

Behrens, T., Scholten, T., 2006. Digital Soil Mapping in Germany - a Review. Journal of Plant Nutrition and Soil Science 169(3), 434-443. https://doi.org/10.1002/jpln.200521962

Carter, M., Bentley, S.P., 2016. Soil Properties and Their Correlations. Chichester, UK: John Wiley \& Sons. https://doi.org/10.1002/97811191 30888.fmatter

Čirić, M., 1984. Pedologija. Sarajevo, Svijetlost.

Gračanin, M., 1951. Pedologija. III dio - Sistematika Tala. Sveučilište u Zagrebu, Zagreb, Hrvaška.

Hartemink, A.L., 2016. The Definition of Soil since the Early 1800s (Chapter 2). Advances in Agronomy, Volume 137. Elsevier Inc, 73-126. https://doi.org/10.1016/bs.agron.2015.12.001

IUSS Working Group WRB, 2015. World Reference Base for Soil Resources 2014 (Update 2015), International Soil Classification System for Naming Soils and Creating Legends for Soil Maps. World Soil Resources Reports No. 106. 1st ed. Rome, FAO.

Kišpatić, M., 1877. Zemljoznanstvo obzirom na šumarstvo i gospodarstvo. Zagreb.

Kralj, T., 2008. Primerjava sistemov zarazvrščanje tal naizbranih tleh v Sloveniji (Doctoral Dissertation). University of Ljubljana, Biotechnical Faculty, CPVO.

Kralj, T., Grčman, H., 2009. Harmonizacija klasifikacije z WRB. Poročila CRP projekta V2 051 DKT-TIS (Vrščaj B., Eds.). Ljubljana, Kmetijski inštitut Slovenije.

Krasilnikov, P., Arnold, R.W., Ibáñez, J.J., 2010. Soil Classifications: Their Origin, the State-of-the-Art and Perspectives. 19th World Congress of Soil Science, Soil Solutions for a Changing World, Brisbane, Australia, 19-22 (DVD).

Krasilnikov, P., Tabor, J., 2010. Ethnopedology and Folk Soil Taxonomies. [In:] Soils, Platnt Growth and Crop Production, Vol III. EOLS Publishers/UNESO, 115-160.

Kubiëna, W.L., 1948. Entwicklungslehre Des Bodens. Zeitschriftfür Pflanzenernährung, Bodenkunde, Vol 52, No 1. Wien, Springer-Verlag, 109-114. https://doi.org/10.1002/jpln.19651100204 
Kubiëna, W.L., 1953. The Soils of Europe (Illustrated Diagnosis and Systematics): With Keys and Descriptions for Easy Identification of the Most Important Soil Formations of Europe with Consideration of the Most Frequent Synonyms. Thomas Murby \& Co, London.

Kubiëna, W.L., 1958. The Classification of Soils. European Journal of Soil Science 9(1), 9-19. https://doi.org/10.1111/j.1365-2389.1958.tb01893.x

Lobnik, F., Vidic, N., Grčman, H., Lisec, A., Šporar, M., Zupan, M., Prus, T., 2006. Tla Slovenije - Pedološka Karta v Merilu 1:250.000. Novi izzivi v poljedelstvu 2006, 193-97.

Lobnik, F., Vrščaj, B., Prus, T., Kralj, T., Šporar, M., Rupreht, J., Tič, I., Zupan, M., 2003. Zasnova metodologije zavrednotenjezemljišč - končnoporočilo. Univerza v Ljubljani, Oddelek za agronomijo, Centerzapedologijo in varstvookolja, Ljubljana.

Lovrenčak, F., 1994. Pedogeografija. Ljubljana, Slovenia, Filozofska fakulteta, Oddelek za geografijo.

Mermut, A.R, Eswaran, H., 2001. Some Major Developments in Soil Science since the Mid-1960s. Geoderma 100(3-4), 403-426. https://doi. org/10.1016/S0016-7061(01)00030-1

Neugebauer, V., Filipovski, Ǵ., Čirić, M., Živković, M., 1963. Klasifikacija zemljišta Jugoslavije. VIII kongres JDPZ, Ohrid.

Nikiforova, A.A., 2019. Soil Classification. [In:] ISKO Encyclpedia of Knowledge Organization. https://www.isko.org/cyclo/soil

Povše, M., Repe B., 2013. Proučevanje zaslanjenih prstislovenske obale (diploma thesis). Oddelek za geografijo, Filozofska fakulteta, Univerza v Ljubljani, Ljubljana.

Prus, T., 2000. Klasifikacija tal Slovenije - študijskogradivo. Univerza v ljubljani, Biotehniška fakulteta, Center za pedologijo in varstvookolja, Ljubljana.

Prus, T., Kralj, T., Vrščaj, B., Zupan, M., Grčman, H., 2015. Slovenska Klasifikacija Tal. Biotehniška fakulteta, Center za pedologijo in varstvookolja in Kmetijski inštitut Slovenije, Ljubljana.

Repe, B., 2006a. Pedogeografska karta in njenauporabnost v geografiji (doctoralthesis). Univerza v Ljubljani, Filozofska fakulteta, Oddelek za geografijo, Ljubljana.

Repe, B., 2006b. Svetovna WRB Klasifikacija Prsti. Geografski Obzornik 53(1). Zveza geografov Slovenije, Ljubljana, 9-22.

Repe, B., 2010. Recognition of the Slovenian Soil Classification Types. Dela, Vol. 34. Oddelek za geografijo, Filozofska fakulteta, Univerza v Ljubljani, 143-166. https://doi.org/10.4312/dela.34.143-166

Repe, B., 2018a. Mednarodni klasifikacij skisistem za poimenovanje tal in izdelavo legend na zemljevidih tal 2014 (Posodobitev 2015). Znanstvena založba Filozofske fakultete, Food and Agriculture Organization of the United Nations, Ljubljana, Rim.

Repe, B., 2018b. Soils in the Slovenian Educational System. Bulletin of Geography. Physical Geography Series 14(1), 99-108. https://doi. org/10.2478/bgeo-2018-0010
Repe, B., Pristovšek, A., 2011. Geografski prispevek k poznavanju subakvalnih prstiob Slovenski obali. [In:] Četrti Melikovidnevi: Geografski vidikiupravljanja z morjem in zaledjem. Univerzana Primorskem, Znanstveno-raziskovalnosredišče Koper, 51-52.

Repe, B., Pristovšek, A., Pavlin, T., 2019. Pedološkiprispevek k poznavanju muljastegadna Slovenske obale. [In:] Strokovna in znanstvena predavanja Pedološkodruštvo Slovenije, 47, Ljubljana.

Simonson, R.W., 1962. Soil Classification in the United States: Classification of Soils at Any Point in History Largely Reflects Current Understanding of Soil Genesis. Science 137(3535), 1027-1034. https://doi. org/10.1126/science.137.3535.1027

Stepančič, D., 1977. Ocenjevanje Tal v SR Sloveniji. Biotehniška fakulteta, Ljubljana.

Stritar, A., 1973. Pedologija (kompendij). Biotehniška fakulteta, Agronomski oddelek, Ljubljana.

Stritar, A., 1990. Krajina in krajinskisistemi. Ljubljana, Slovenia, Partizanskaknjiga.

Skorić, A., 1977. TipoviNaših Tala. Zagreb, Liber.

Skorić, A., 1986. Postanak, razvoj i sistematika tla. 1986. Zagreb, Sveučilište u Zagrebu.

Škorić, A., Filipovski, G., Ćirić, M., 1973. Klasifikacija Tala Jugoslavije. Poljoprivredni i šumarski fakultet Zavod za pedologiju Zagreb.

Škorić, A., Filipovski, G., Ćirić, M., 1985. Klasifikacija zemljišta Jugoslavije. ANU Bosne i Hercegovine, Sarajevo.

Urbančič, M., Simončič, P., Prus, T., Kutnar, L., 2005. Atlas gozdnih tal. Zveza gozdarskih društev Slovenije, Gozdarski vestnik in Gozdarski inštitut Slovenije, Ljubljana.

Vidic, N.J., Prus, T., Grčman, H., Zupan, M., Lisec, A., Kralj, T., Vrščaj, B., 2015. Tla Slovenije s pedološko karto v merilu 1:25,000. Evropska komisija, Skupnirazisko valnicenter (JRC), Luxembourg. http://dx.doi. org/10.2788/88750

Vrščaj, B., Grčman, H., Kralj, T., Prus, T., 2019. Klasifikacija Tal Slovenija 2019: Sistem zaopisovanje in poimenovanje tal Slovenije (Delovnogradivo). Pedološkodruštvo Slovenije, Ljubljana, Slovenia.

Vrščaj, B., Prus, T., 1998. European Soil Database (Scale 1:1,000,000) - Slovenia. Ispra, Italy, Joint Research Centre.

Vrščaj, B., Repe, B., Simončič, P., 2017. The Soils of Slovenia. Springer, Dordrecht. https://doi.org/10.1007/978-94-017-8585-3

website 1: https://www.merriam-webster.com/dictionary/classification

website 2: http://www.fao.org/soils-portal/soil-survey/soil-classification/ en/

website 3: https://www.cliffsnotes.com/study-guides/biology/plant-biology/systematics/types-of-classifications

website 4: http://rkg.gov.si/GERK/documents/PedoloskaKarta.zip 